\title{
Clown and Fool as Voice in Earth Activism
}

\author{
Megan Hyslop
}

Megan Hyslop feels grateful to find herself living well with others in beautiful rural Nova Scotia/Mi'kmak'i. Megan, who had a great upbringing on the prairies and west coast of Canada and is of mixed European ancestry, is an energy worker, artist, naturalist, and $\mathrm{PhD}$ student with the interdisciplinary Individualized Program out of Concordia University. She is a member of Theatre Nova Scotia and has studied at the Manitoulin Conservatory for Creation and Performance, Nose to Nose, Caserne 18-30, and Leviathan Studio. Email: meganhyslop@yahoo.ca

How can the human relationship with the other-than-human be reenvisioned as neither destructive nor redemptive but as dynamic and playful? I explore ways that the archetype and practice of the fool and theatrical clowning could highlight this fundamental connection. This autoethnographic performative study draws on the work of such play theorists as Huizinga, Carse, Nachmanovitch, Winnicott, Bateson and Martin, Ackerman, and leadership visionary Wheatley. It is a dance between stories and literature that gives examples of play as a way to navigate and imagine a heart, mind, and body engagement with community.

Key words: earth activism; more-than-human; clown; fool; relationship; dance

How might playful dance, playful drama, and playful creative community look through the eyes of these theorists?

Earth activism is often goal oriented, relying on words to make arguments, convince, persuade. In my experience, it sometimes feels like a battle: staving off a tide of plastic, oil spills, broken water, broken land.... There is no new language here, just pain. However, the playful-serious dance of Plato's eutrapelos archetype, the pure potential of fool, the all-encompassing order-disorder creation-destruction of trickster, offers the possibility to unhinge tired compilations and bewitch new, unlikely unions, healing any seeming discrepancies with love (Ardley, 1967; Laird, 2001; Nachmanovitch, 1990; Sutton-Smith, 1997). This process is ongoing when we attend to it: the snow that covered the mountain last week in the crystal-winter clarity of white streaming down yesterday over rocks and down the gulleys beside the path, the flight of the first pair of mourning cloak butterflies. The repeating but always different "pointless" and tangential actions of play, the surprise combinations with space for luminous tangents, the curious, wandering, relaxed, roughhewn, and repetitive (Bateson \& Martin, 2013) can provide balance and help us discovery new truths, possibilities, and ways of being. 


\title{
Playful Movement: Back to Source
}

\author{
Entre tus hojas como \\ Suave guiso \\ Crecieron nuestros graves corazones \\ De niños provincianos \\ Y comenzó la vida \\ A desgranarnos
}

(Within your husks/like gentle kernels/our sober provincial/children's hearts were nurtured/until life began/to shuck us from the ear. [Neruda, 2013, "Ode to Maize"])

In clowning, we talk about clowning as return to innocence, to a child-like state, after the experiences of adulthood. Last week, feeling cramped and grumpy from my work week, I went to the Tam Tams drumming and dancing jam at the angel statue at the base of Mont Royal here in Montréal. To my surprise, I stayed almost three hours, shaking my hips and shaking off the winter. My movements at first felt stiff, like I was outside myself watching ... dance like no one's watching ... yeah right! Everyone is watching! After a time of bare feet on ground, drum vibration, cow bell ting ti-ting ti-ti-ti ting, and the warm sun on my face, I felt a shift to a kind of not-feeling-not-thinking-both-and, a kind of tap-in to the play instinct of movement, action, and body consciousness (Bayliss, 1999; Nachmanovitch, 1990). I started to goof around in my dance, arms wide up and around, flamenco moves, spinning around, my face got into it, my hands, my knees. Minutes afterwards, an artist-activist friend of mine showed up beside me and gave me a hug. "I'm so tired, but I love watching you dance!" she said. I invited her in with my face and eyes, and we started a spontaneous back and forth, make a move, share a move, kind of light-bright dance, facing the sunshine and the trees and the djembes. When it was time for her to go she said, "I'm serious, you know, I'm serious all the time, but it felt so good to see my movements mirrored back to me with humour. It feels good to laugh."

Huizinga (1950) wrote that "play and culture are actually interwoven" (p. 5). I imagine a culture that is braided with the complexity of dance, an art form that is both matter/body bound/limited and aesthetically rich/patterned/ moving (p. 166). Huizinga called this complexity anomalous, but imagine if it were commonplace and normalized. The moving play of dance, like other forms of play and creativity, is a way to engage the whole person so the big Self, or true Source self (Johnson, n.d.; Winnicott, 1971) can emerge. If one function of play is to practice new patterns of beingness, alone or with other people, and, I would add, with the more than human (Bateson \& Martin, 2013), could we dance in response to earth violence, which is, in a sense, violence against ourselves (Bramadat, 2015)? One of the more moving responses I have seen to violence and harm is the playful and embodied expression of dance. In the Montréal-Colombian dance/movement collective Salsa Descalza manifesto (n.d.), they say that they

resist through dancing, to combat the monotony and the cold through movement, to express with the body the pain and the laughter, to assemble the solitudes and to build from the numerous gifts of our full and intense existence. We dance because the possibility of existing is in danger. (para. 1, translated by the author)

Change is painful, said dance and philosophy professor Erin Manning in my research-creation class. Laird (2001) writes that creative energy "lies buried in the heart of the wound" (p. 87), and that richness and wisdom comes from passing through the affliction, from "the racking pain inflicted by life's indifference" (p. 86). Authentic, creative work is both alight in its liberatory potential and frightening in the shuffle-feeling-forward in the disorientation of 
darkness and through blocks of fear and sadness. Laird says we must be willing to be dismantled by these feelings, willing to fail utterly to reach the truth of the work, of the moment, and of the loving relationships around us (Wheatley, 2009). Such paradoxes, writes Johnson (n.d.), tell us we are close to Source, to authentic self. Rather than resolve them, control them, or parse them (Ardley, 1967), we can see them as eternal movement and change (or play) and ultimately transform our relationship to this "mutual and incessant modification" (Turner, 1982, p. 108).

The little boy and his mother are leaving the café now. As she stands in the sun talking on her phone, he returns to the front door and opens it, calls out a salut to everyone in the café, and points out the small black bear on top of the ice cream cone sign as they walk down Villeneuve. I wave back, enchanted.

\section{Playful Theatre: Playing With Fire}

"I like your red tutu," says a customer at the café as I stand up to get a drink of water. "When I worked at a daycare, this was how children would dress when they chose for themselves."

Some theorists from this course write that play must be freely chosen and apart and an act of free will (Bateson \& Martin, 2013; Caillois, 1958). Carse (1987) writes that there is play which is temporally and spatially bound (finite) and play that is ongoing and free of time and space constraints, and that the entirety of life is an infinite game. This assertion reframes Caillois's (1961) proposition of competition, chance, simulation, and vertigo as basic instincts that need to be channelled into games.

Turner (1982) writes that in more agrarian contexts, work merged gently with play in a rolling rhythm with specific rituals (sacred work) for liminality and communitas. The modern onset of industry created a separation between work and leisure, and that leisure/play has become liminoid, perhaps more free than the obligatory rituals of the past, but also more commodified. Other theorists say that play is in the spirit of maya-lila, a primordial performative-creative act of continuous playing, a multitude of changing realities of Divine order (Bayliss, 1999; Huizinga, 1950; Nachmanovitch, 1990; Sutton-Smith, 1997), and that to separate jest and earnestness "frustrates both" (Ardley, 1967, p. 231). Winnicott (1971) writes that when we live creatively, we see life as infused with potential. Because life is fluid, we can lose this creative "this is play" (Bateson, 1976) definition of living; at the same time, the act of playing can help us connect to this spirit again.

In February, I performed a clown turn, or skit, with two others at the free, vegan People's Potato meal servings at Concordia University, ridiculous skits about buying a small bell and wrapping it in ten reusable bags, about oilclowns spilling out from under a line of chair-pipelines. My goal is to see audience reactions, I say. Do they open up? Do they close down? Before we begin the turn, we circulate around the space and engage with students waiting in line. Some students blush and avoid eye contact, some continue with their reading or computer work when I approach them. A man arrives to sit with his friends with a Tupperware container. I reach my hand toward it, delighted, waiting for his permission to touch the container. He holds it out toward me, and I flip open one of the latches and laugh.

Nachmanovitch (1990) writes that Buddha articulated five basic human fears, one of which is fear of being thought a fool, another, fear of actually being a fool. What might the neighbours think if we give in to a playful life, writes Ackerman (1999)? However, I am learning that giving voice to my exuberant, contradictory, and sometimes foolish emotional life and path takes much less energy than trying to control it; it centers and relaxes me. Bayliss (1999) says this playfulness can feel volatile (unpredictable), explosive (unexpected and suddenly opening), and dangerous (risky with potential for failure and loss), but that it is a "primary human function" (p. 74). It transforms, 
it strengthens, it revives, it illuminates (Pinkola Estes, 1992).

"But we have to talk about things if they're going to change ... don't we?" said someone in my clowning class, implying serious talk, planning talk, militant talk.

I wasn't so sure. In my philosophy class we talked about opening space for speaking in the richness of the now, the ever-moving, creative, and often wordless and half-baked modality of intuition and feeling. As we talked about in this play class, this also gives other avenues to expression and response beyond spoken communication, such as metacommunication and body language that signals ongoing dialogue in the form of play (Bateson, 1956; Nachmanovitch, 2009).

Carse (1986) writes that the infinite speech of the wordlessness of nature, and, by association, of the body, "bears no claim to truth, originating from nothing but the genius of the speaker" (p. 108). Ardley (1967) writes that while just playfulness turns to frivolity, just seriousness to rigidity, and pseudo-seriousness to imprisonment, playfulseriousness allows us to play with the tragi-comedy of life. To invite the fool spirit, said a hospice clown I spoke with recently, is to be vulnerable, to poke fun at self, to risk embarrassment through silliness, to laugh with, not at, people, and to remember the deeper goal of connection and support, of walking with someone through grief (Janet Stark, spiritual care manager and multifaith chaplain, personal communication, April 15, 2015).

In other words, play is a way to stay in the heart of possibility, creativity, and inner Source, no matter what the exterior emotional temperature (Boven, 2014; Johnson, n.d.). Landy (1996) writes that we are nothing but roles in an ever-shifting definition of self, and that an intention of health is not to hold on to any one of these roles, but to expand the self outward to include more possibilities of response. As Nachmanovitch (1990) writes, we as humans are simultaneously both the greatest enemy and the greatest creators and composers. Rather than taking the role of student, activist, social changer, or fool, I can be devotion (Wheatley, 2009), action, balance, and creative potential. This, writes Carse (1986), keeps the playing dramatic, moving toward an open horizon, vulnerable, and always in play with others. When I saw a friend in line the following week at People's Potato, she said that she and her friend had just been talking about whales and oil tankers, that she had heard of the clown turn, and that she was glad for a way to talk of things in a different way, in a lighter way.

\section{Playful Community: Toward the Horizon}

\section{Micropolitics as transversal and relational (Erin Manning).}

"Would you like to talk about a $\mathrm{PhD}$ as a way to grow into a community?" a colleague asked me recently via email. "Often it is the other way around." I think that what he is talking about is belonging: to be rightly placed, to fit in a specific place or ambience, to pertain. The nomadic life lends a broad definition of home, belonging, and community: Basho says it is the open road, the living day, the voyage, and the journeying itself (Bureau of Public Secrets, n.d.). Play for me is most beautifully a community connection that is joyful, warm, and fluid in its oscillations and modifications among people, ecosystem, and self. It is a path to dramatic expression and the brilliance of the body in movement, these elegant ships that sail us on the journey. Last night my farming friend told me he is taking over his parents' farmhouse on the land where he farms in Nova Scotia, that he hopes to create a collective home for his gardener and artist friends on his forested, fertile land. My mind flashed back to our long weeding sessions under the blue of the Annapolis valley skies, the words I want to teach permaculture and clowning play and we should start an ecovillage together that flew out of my mouth on two different occasions, and then forward to the image of a bursting-to-the-brim, exuberant, and galumphing house. 
“I feel a yearning for that, but I don't think I can live in a household of hippies," I told him brusquely, feeling a slight panic at this advancing potential of what was dreamed.

Say yes is the first rule of improvisation. In my process philosophy/creativity class, Erin Manning called this a politics of affirmation. It playfully encourages new ideas to take root while acknowledging that not all ideas will make it to fruition. Rather than consensus with others, it asks for commitment to the creative process and attentiveness to the shifting dynamics and emerging energies of the group.

Like Bateson and Martin's (2013) novelty, fluency, and flexibility in affirmative brainstorming, Nachmanovitch (1990) calls this "Yes! Yes! Yes!" (p. 55) affirmation of what is before us the simplest devotion to deep play. Rather than the shrinking qualities of "No, no, no," a yes to the beingness of a flower, a person, a brick wall opens the universe of possibilities “in a matter of mere moments" (p. 55). In Ackerman's (1999) and Cameron's (1992) writing on deep play and creativity, they use words like reverence, aliveness, presence, rapture and ecstasy, wholly-holy enthusiasm and love, pleasure and child's play. In their writing is a marked lack of words like discipline, focus, and restraint. Like the Cooper's hawk I have been communing with this spring on Mont Royal, this "dangerous" (Bayliss, 1999) deep play can take us for a ride in its talons as we merge into the experiencing, living moment.

The second rule of improvisation, don't block, comes, I believe, from the fear of losing control, or of appearing out of control, or perhaps imagining that we can impose control (Ackerman, 1999) when playing for play's sake. Nachmanovitch (1990) and Carse (1986) write that free play flows easiest when neither player nor played seeks to control or be controlled but can dance together in lavish abundant time toward an ever-shifting horizon. Wild plants grow on their own accord, in the light that best suits them, in the perishing soils of other seeds and seedlings who have ceded space.

Yesterday, a redheaded downy woodpecker made me laugh as he popped his head repetitively in and out of a dead tree and chirped for no apparent purpose. I remembered my new nature-mentor's suggestion to take the time to observe the actions of a bird, not just the first motion, but to look there within for the pattern. After the tenth or eleventh repetition, the woodpecker brought up a beakfull of sawdust every other time, and after the nineteenth or twentieth time, I began to hear drumming from inside the log.

Ardley (1967) writes that by connecting to a God of ever-changing yet rhythmic and repetitive play, it breaks open our illusions of separateness and opens us, I believe, to interconnectedness and the beauty of relationship. Rather than take me off an imagined course, he says, "it matters little where we start and what road we take. If we have the love of truth, we shall reach the summit all the same" (p. 237).

Today in the café, I find that writing in the definition of play (Nachmanovitch, 1990) softens and slows me. I am able to greet and hug a friend who comes by chance for a coffee, admire the small sailboat boots of my table companion, tune in and out to the jazz music playing. At the same time it loosens and releases me into my flow of writing. Before I began the course on play, I assumed that risky, volatile play and galumphing were somehow related to creativity and creative living, and that creativity was related to essential self and self-knowledge, connection to Spirit, and self-loving. However, life as a rollicking infinite game didn't always seem sustainable to me (Carse, 1986). I also assumed there were different qualities of play, but didn't have a frame through which to view them.

My assumptions were affirmed and articulated in a number of different ways. In the readings, I've learned that play comes from divine Source (Ardley, 1967), leads to creative living potential (Winnicott, 1971), and connects us with Source self (Johnson, n.d.) as an essential human function and evolutionary value (Bayliss, 1999; Nachmanovitch, 1990). I also learned about different frames of play, particularly the tension (Carse, 1986) between finite play as temporally and spatially defined (Bateson \& Martin, 2013; Caillois, 1961) and infinite play as infused, ongoing 
play-performance creation (Ardley; 1967; Bayliss, 1999; Nachmanovitch, 1990; Winnicott, 1971).

Curiously, I felt most resistant to Ackerman's approach to play as I began the course and the most affinity to it as I finish. The kind of deep play she writes about with such affection reminds me of Campbell's (2004) encouragement to follow one's bliss, doing "what you absolutely must do to be yourself" (p. xxiii). It is a joyful lightening to remember that I can literally play my part in loving the planet and its people and creatures. Beck (2012) uses the word "wayfinder," after ancient Polynesian navigators who know how to "read" ocean patterns, to describe the techniques of sacred play, imagination, and personal creation practice used by modern-day "menders" of human nature: "Dear Humans: Save yourselves, I'll be fine. Love, Earth" (p. xxii). She writes that these unique expressions of true nature are when we catch ourselves in deep play; in our "wild new world" this deep play is compelling and the kind of technology we need to heal.

I received an email this morning about my playful-serious farmer friend's galumphing escapades over the weekend in Halifax, out playing until early morning with his former roommate and sleeping on her too-short couch before a day of rip-roaring sales at the market. I spent a similar, albeit more low-key, weekend writing my heart out, planting lemon cucumber and broccoli raab seeds in cutoff juice containers, and dancing in the ganja-hazy cloud of drumming hippies at the afternoon Tam Tams at Mount Royal.

After reading the email, I went to the Place Desjardins mall to speak to an agent about my taxes (double horror!) and found myself calm and breathing, charmed by the blue fountain, Shania Twain music, and Tiki-Ming and Saint Cinnamon food kiosks. Somehow my habitual judgments and will to wrangle things into the good or bad box were silent, and the perfection, absurdity, and poetry of my inner and outer surroundings blended together in a soft hum. For me, this shift of heart-mindset feels sustainable as infinite game, more so than play as finite and the rest of life as solemnity, or earth connection as finite and the rest of life as heroic mission.

How does/will the spirit of fool infuse my gardening projects and nature awareness sessions as learner and as teacher? Might the hippie household be game for movement and clown experimentation as play and healing practice? What will be the responses in different performance venues, in myself and in others, and who will be my collaborators? What happens when I give an enthusiastic yes yes yes as the simplest act of deep play to this work?

\section{References}

Ackerman, D. (1999). Deep play: Harvesting joy from the games of life. New York, NY: Random House.

Ardley, G. (1967). The role of play in the philosophy of Plato. Philosophy, 42(161), 226-244.

Bateson, G. (1976). A history of play and fantasy. In R. Schechner (Ed.), Ritual, play, and performance (pp. 67-73). New York, NY: Seabury Press.

Bateson, P., \& Martin, P. (2013). Play, playfulness, creativity, and innovation. Cambridge, England: Cambridge University Press.

Bayliss, A. (1999). Playing with words: An exploration of ludic terms and the linguistic permeation of play in a cultural context. Research in Drama Education, 4(1), 73-84. doi: 10.1080/1356978990040106

Beck, M. (2012). Finding your way in a wild new world: Reclaim your true nature to create the life you want. New York, NY: Free Press.

Boven, M. (2014). Incognito. In KRSRR, Volume 15, Kierkegaard's concepts, Tome III: Envy to incognito (pp. 231-236). Hampshire, England: Ashgate.

Bramadat, D. (2015). A new, green world. Hither and Yon blog. Retrieved from: https://dawnbramadat.wordpress.com/2015/04/01/a- 
new-green-world/

Bureau of Public Secrets. (n.d.). Matsuo Bashô: Oku no hosomichi. Nine translations of the opening paragraph. Retrieved from: http:// www.bopsecrets.org/gateway/passages/basho-oku.htm

Caillois, R. (1961). Man, play, and games. New York, NY: The Free Press.

Cameron, J. (1992). The artist's way: A spiritual path to higher creativity. New York, NY: Penguin Putnam.

Campbell, J. (2004). Pathways to bliss: Mythology and personal transformation. Novato, CA: New World Library.

Carse, J. (1986). Finite and infinite games: A vision of life as play and possibility. New York, NY: The Free Press.

Huizinga, J. (1950). Homo ludens: A study of the play element in culture. Boston, MA: Beacon.

Johnson, D. (n.d.). Developmental transformations: Towards the body as presence. Retrieved from: http://www.developmentaltransformations.com/images/Chapter_6_Johnson_final.pdf

Laird, R. (2001). Grain of truth: The ancient lessons of craft. Toronto, ON: MacFarlane, Walter, \& Ross.

Landy, R. (1996). Essays in drama therapy: The double life. London, England: Jessica Kingsley.

Pinkola Estes, C. (1992). Women who run with wolves. New York, NY: Ballantine.

Nachmanovitch, S. (1990). Free play: Improvisation in life and art. Los Angeles, CA: Jeremy P. Tarcher.

Neruda, P. (2013). Ode to maize. In I. Stavans (Ed.), All the odes. New York, NY: Farrar Strauss Giroux.

Salsa Descalza. (n.d.). About me. Retrieved from: http://salsadescalza.blogspot.ca/

Sutton-Smith, B. (1997). The ambiguity of play. Cambridge, MA: Harvard University Press.

Turner, V. (1982). From ritual to theatre: The human seriousness of play. New York, NY: Performing Arts Journal Publications.

Wheatley, M. (2009, March). The place beyond fear and hope. Shambhala Sun. Retrieved from: http://www.margaretwheatley.com/ articles/BeyondHopeandFear.pdf

Winnicott, D. W. (1971). Playing and reality. London, England: Tavistock. 